Images in...

\title{
Traumatic left anterior descending to pulmonary trunk fistula
}

\author{
Saissan Rajendran, ${ }^{1,2}$ Wenxiao Zhou, $^{1}$ Christoph Juli, ${ }^{3}$ Prakash Punjabi ${ }^{1}$ \\ 1Department of Cardiothoracics, Imperial College Healthcare NHS Trust, Hammersmith Hospital, London, UK; \\ 2University of New South Wales, Kensington, New South Wales, Australia; \\ ${ }^{3}$ Department of Radiology, Imperial College Healthcare NHS Trust, Hammersmith Hospital, London, UK
}

Correspondence to Dr Saissan Rajendran, saissanrajendran@hotmail.com

\section{DESCRIPTION}

A young man in his late 20s, presented with new-onset exertional angina. Five months earlier, the patient had presented to the trauma unit with a penetrating injury to the left chest and cardiac arrest due to cardiac tamponade. The

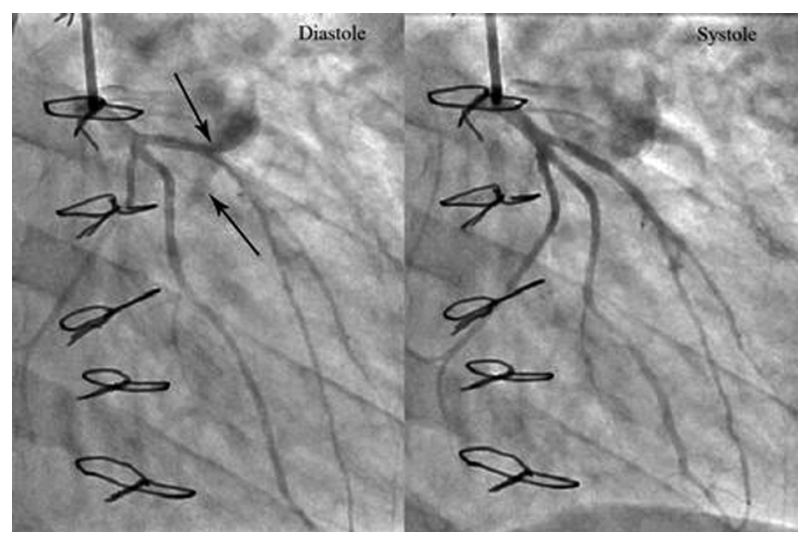

Figure 1 Coronary angiogram of left coronary system demonstrating high flow shunting between proximal $L A D$ and PT (left, upper arrow), and contrast filling within the myocardium (left, lower arrow). Both defects are dynamic and close during systole (right).

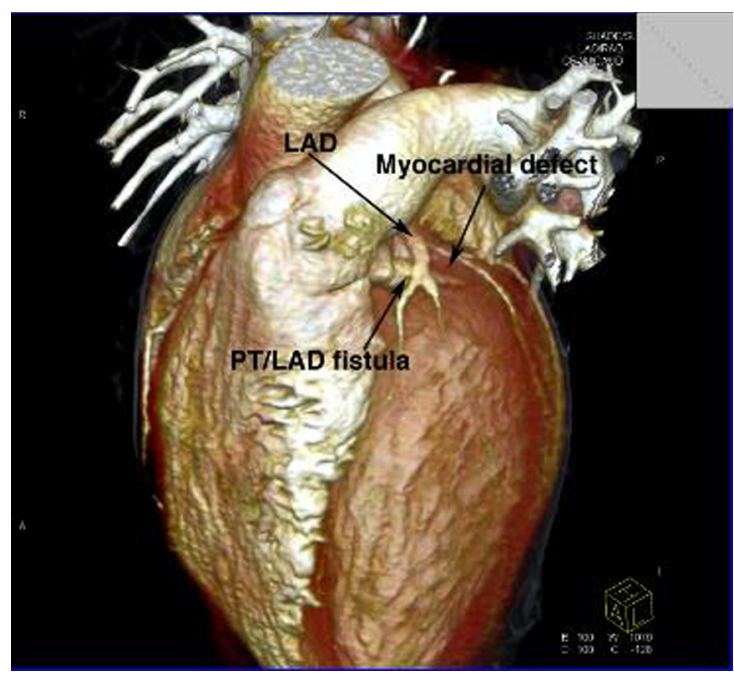

Figure $23 \mathrm{D}$ reconstruction of cardiac CT angiogram demonstrating $8 \mathrm{~mm}$ cross-section fistula between PT and LAD, and $4 \mathrm{~mm}$ myocardial defect. patient had undergone emergency median sternotomy for repair of a $15 \mathrm{~mm}$ laceration to the right ventricular outflow tract. On examination, he had normal vital signs with no abnormal heart sounds or signs of heart failure. ECG was normal. Cardiac catheterisation demonstrated a communication between the proximal left anterior descending coronary artery (LAD) just before its first diagonal branch and the pulmonary trunk (PT) (figure 1, upper arrow). A small blind-ended myocardial defect was also visible transiently at the same site (figure 1, lower arrow). Both defects were dynamically occluded during systole (figure 1). The LAD-PT fistula measured $8 \mathrm{~mm}$ in diameter and the myocardial defect measured $4 \mathrm{~mm}$ on CT (figure 2). Laboratory investigations were normal. Surgery was performed on cardiopulmonary bypass. The PT was opened exposing an $8 \mathrm{~mm}$ fistulous connection with the LAD within the right ventricular outflow tract, distal to the septal leaflet of the pulmonary valve (figure 3 ). The fistula was closed with 4/0 prolene suture. Coronary artery fistulas maybe congenital or acquired abnormalities. They are identified in only $0.2 \%$ of routine cardiac angiographic studies ${ }^{1}$ and can vary widely in morphologic appearance and presentation. Acquired coronary artery fistulas are rare, but $80 \%$ are secondary to penetrating injuries. The rarity of acquired coronary fistulas can be attributed to the high death rate $(65 \%$ to $85 \%$ ) of penetrating wounds involving the coronary

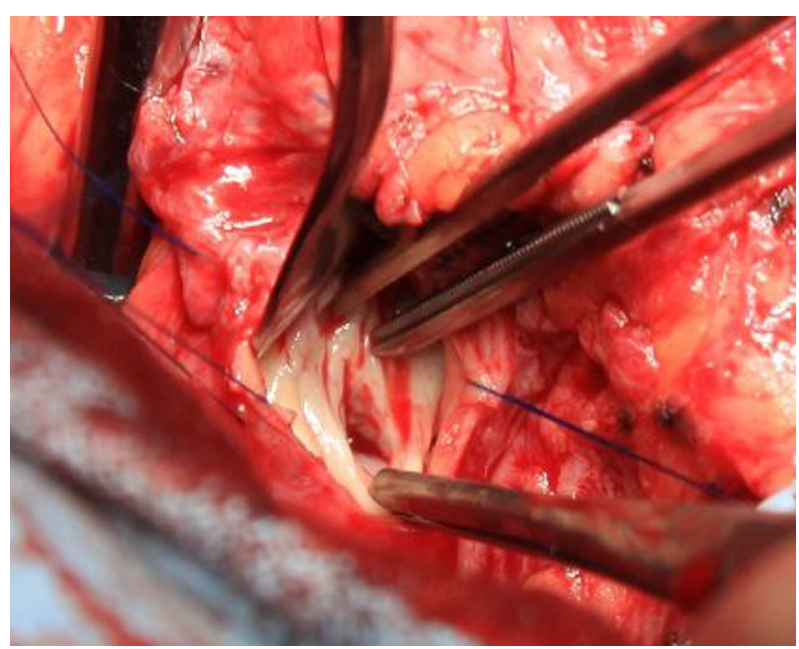

Figure 3 Intraoperative photo demonstrating the opened PT showing an $8 \mathrm{~mm}$ fistula opening. An inserted probe was able to reach the LV. 


\section{BMJ Case Reports}

arteries. $^{2}$ Time between injury and presentation may be days to decades, averaging 3 years. ${ }^{3}$ Early intervention is paramount to avoid progression of functional myocardial impairment and increasing operative risk. Late complications of high flow left to right shunting, including the development of pulmonary artery hypertension and congestive cardiac failure have also been documented. Repair may be either external closure of fistula, or internal closure from within the recipient chamber, with the latter having a lower recurrence rate. ${ }^{3}$
Competing interests None.

Patient consent Not obtained.

\section{REFERENCES}

1. Hobbs RE, Millit HD, Raghavan PV, et al. Coronary artery fistulae: a 10-year review. Cleve Clin 0 1982;49:191-7.

2. Heller RF, Rahimtoola SH, Ehsani A, et al. Cardiac complications: results of penetrating chest wounds involving the heart. Arch Intern Med 1974:135:491-6.

3. Hancock Friesen C, Howlett JG, Ross DB. Traumatic coronary artery fistula management. Ann Thorac Surg 2000;69:1973-82.

This pdf has been created automatically from the final edited text and images.

Copyright 2012 BMJ Publishing Group. All rights reserved. For permission to reuse any of this content visit http://group.bmj.com/group/rights-licensing/permissions.

BMJ Case Report Fellows may re-use this article for personal use and teaching without any further permission.

Please cite this article as follows (you will need to access the article online to obtain the date of publication)

Rajendran S, Zhou W, Juli C, Punjabi P. Traumatic left anterior descending to pulmonary trunk fistula. BMJ Case Reports 2012;10.1136/bcr.12.2011.5333, Published XXX

Become a Fellow of BMJ Case Reports today and you can:

- Submit as many cases as you like

- Enjoy fast sympathetic peer review and rapid publication of accepted articles

- Access all the published articles

- Re-use any of the published material for personal use and teaching without further permission

For information on Institutional Fellowships contact consortiasales@bmjgroup.com

Visit casereports.bmj.com for more articles like this and to become a Fellow

Keep up to date with all published cases by signing up for an alert (all we need is your email address) http://casereports.bmj.com/cgi/alerts/etoc 